ROCZNIKI HUMANISTYCZNE

Tom LXVIII, zeszyt $11-2020$

DOI: https://doi.org/10.18290/rh206811-12

\title{
CARIBBEAN LANDSCAPE AND THE CONSTRUCTION OF CREOLE CONSCIOUSNESS IN JEAN RHYS'S WIDE SARGASSO SEA*
}

\begin{abstract}
A b stract. This article aims to analyse the relationship between the depiction of place and the construction of Creole identity in Jean Rhys's 1966 novel Wide Sargasso Sea. My main contention is that the novel's Dominican protagonist undergoes an evolution in her Creole consciousness, and that this evolution is manifested in her varying degrees of (dis)connection with Dominica's nature. Accordingly, this character-narrator reflects the link between place and identity by recalling certain events belonging to her past and, most importantly, her interaction with Caribbean landscape at different stages of her life in her native place. By examining the relationship between identity formation and Caribbean landscape, this article attempts to widen the scope of literature on memory retrieval in Jean Rhys's fiction while casting new light on the paramount role of the Caribbean landscape in Wide Sargasso Sea.
\end{abstract}

Keywords: Jean Rhys; Caribbean landscape; Creole identity; memory studies; Wide Sargasso Sea.

\section{INTRODUCTION}

Jean Rhys is a complex author who cannot be easily placed within a specific literary tradition. Indeed, she is a liminal writer who wrote both modernist and postmodernist works. Linked to that liminality in terms of period, her multifarious identity should be foregrounded: she was a Caribbean white Creole of British origin. Yet, such a complex identity became problematic for Rhys

Alejandro NadAl-Ruiz is a PhD student at the Department of English and German Philology, University of Zaragoza; address for correspondence: Facultad de Filosofía y Letras, Calle San Juan Bosco, 7, 50009, Zaragoza, Spain; e-mail: anadal@unizar.es; ORCID: https://orcid.org/0000-00015620-8300.

* The research for this article has been funded by the Spanish Ministry of Universities (FPU18/00782 and FFI2017-84258-P) and by the Government of Aragon (H03_20R). 
because she felt that she did not belong anywhere. This feeling gradually became a malady of the spirit that haunted her throughout her career and that gave shape to her most celebrated characters. The most outstanding work of Rhys's literary production is her late novel Wide Sargasso Sea (1966). This work is representative of its author's multiple facets since its protagonist is a white Creole named Antoinette who also participates in different cultures: the British and the Caribbean. However, as is the case with both Rhys and her previous female characters, Antoinette grows displaced and emotionally helpless due to her Creole consciousness.

The sources of Antoinette's dejection can be better understood through an analysis of how, as the main internal narrator of the novel, she recollects her past. She relies on memory in order to present a sketch of her life in Dominica and, most importantly, how she reacted to some important events of her past. Hence, Antoinette's memories prove a valuable testimony that helps us understand the identity formation of this white Creole and the multifariousness of the island where she was born. Together with Antoinette's use of memory, another means helps readers to better understand the variety of characters that inhabit the small island of Dominica: the relationship between characters and the island's natural world. Not all the characters feel equally attached to the Caribbean landscape, and their (dis)connection with the land shows differrent types of identity and varying degrees of self-consciousness. Researchers such as Delia Caparoso-Konzett, Jessica Gildersleeve, and Carine Mardorossian have analysed how these characters relate to the Caribbean natural world, highlighting the stark opposition between the Caribbean natives' confidence to walk through the beautiful yet dangerous forests of Dominica and the English characters' sense of being trapped in the middle of a landscape they are unable to control. To those studies this work adds an insight into the relationship between Rhys's depiction of the Caribbean landscape and Antoinette's (dis)connection with her native land from the outset of the novel to its ending.

My main contention in this article is that there is a relationship between the Caribbean landscape as recollected by Antoinette-as-narrator and this female character's Creole consciousness. Indeed, Antoinette's different degrees of attachment to the natural world of Dominica reflect an evolution in her sense of deracination as a woman who feels uneasy in her native country. Therefore, I aim to cast light on the relevance Creole consciousness has to the formation of Antoinette's identity and on how the evolution of her identity is suggested by her depiction of Caribbean landscape. Furthermore, I also attempt to bring to the fore the key role of memory in Antoinette's reshaping 
of her changing attitudes to the natural world of Dominica. Methodologically, I approach this novel from the field of memory studies with a view to pinpointing how the internal narrator's recollection and representation of Caribbean landscape enhance her mutating attachment to Dominica. Having selected both descriptive and evaluative passages dealing with Dominica's nature, I close-read them so as to identify to what extent Antoinette is attached to the Caribbean landscape and how her connection to the natural world reflects the evolution of her Creole consciousness. This analysis elucidates three stages in the evolution of Antoinette's cultural identity: an initial sense of utter displacement, as enhanced by the portrayal of Caribbean landscape as a threatening space; an increasingly strong affinity with the island's nature even if Antoinette sometimes shows perplexity about her identity; and final identification with her native land as confirmed by the Creole's free associations while in the attic of her husband's English mansion.

\section{LANDSCAPE AND THE COLONIAL SUBJECT'S IDENTITY}

In her article "Trends in Literary Trauma Theory," Michelle Balaev argues that "we can understand place as the locus where nature and culture converge to construct meaning and inform both individual and collective identity" (160). This contention reflects interrelationship of memory, place, and the search for meaning. Indeed, place is a complex reality where different elements converge and which does not affect exclusively a specific person in isolation but has influence beyond the individual. As well as informing individual and collective identity, place has a fundamental role in constructing meaning (Balaev 160). This is certainly the case in Wide Sargasso Sea, since the Caribbean landscape depicted there contributes to shaping the characters' and especially the protagonist's changes and identities. As posited by Kirmayer et al., "the reconstructions of memory always occur in social contexts that warrant certain types of story as more or less credible" (9). The social and cultural context depicted in Wide Sargasso Sea is the British-colonial period, which relegates the Dominican Creole to the position of subordinate to the English colonisers. Indeed, the protagonist notices her inferior position in the social hierarchy of both the island and the metropolis: in Dominica, Antoinette is the victim of her narcissistic husband's plot to exert his power both in the marital sphere and in the colony; her subordination is 
worsened when she is taken to England and ultimately locked in the attic of her husband's mansion.

From this inferior position, Antoinette reconstructs a series of memories of her life in Dominica whose interest lies in their subversive nature. Such memories eventually become subversive because Antoinette brings to the fore her relationship with the geography, people and folklore of the colony while narrating the story from the metropolis. Therefore, her memories become what the French historian Pierre Nora calls a milieu de mémoire, "an integrated memory, all-powerful, sweeping, un-self-conscious and inherently present-minded" (Nora 2). Indeed, as Astrid Erll argues, milieux de mémoire "may even be a site of 'counter-memories' to the official narrative of the past" (310; emphasis added). This subversive potential characterises Rhys's novel, since it is a postmodern rewriting of Charlotte Brontë's Jane Eyre from the perspective of Rochester's Creole wife. As Elaine Savory observes, this rewriting enabled Rhys to "revision Jane Eyre's lurid description of the Creole wife, which reflected nineteenth-century British stereotypes about white Creoles" (79). Hence, the memories of this novel's internal female narrator could be considered a counter-narrative aimed at overcoming essentialist views of Creole identity, an identity whose complexity was neglected during the colonial period. Along the same lines, Veronica Marie Gregg argues that "in rewriting the Victorian novel, [Rhys] is calling into question the entire Book, the metatext of the dominant, metropolitan discourse" (84). Hence, one of the objectives of Rhys's novel is to challenge the prominence of the coloniser's discourse during the Victorian Era by foregrounding the voice of colonial subject: the silenced Bertha Mason. Likewise, Raffaella Antinucci contends: "The novel itself can be read as a landscape resulting from the act of writing back from the margins, a journey into the 'heart of otherness"” (283). Besides highlighting Rhys's writing back, Antinucci forefronts the paramount role of landscape in the novel and connects it with otherness. Indeed, Wide Sargasso Sea shows a close relationship between Dominica's natural world and cultural identity, and so landscape proves a key element for understanding the complexity of the hitherto marginal identity of the colonial subject. 


\section{FROM AN EDENIC GARDEN TO A HELLISH LANDSCAPE}

The story in Wide Sargasso Sea begins shortly after the 1833 Emancipation Act, whereby slavery was abolished in Dominica. Slaveholding families were legally forced to grant freedom to black slaves. In the case of Creole planters, the consequences of this law were even more detrimental as they gave rise not only to economic hardship, but also to emotional helplessness. As Antoinette suggests in the opening lines of the novel, "they say when trouble comes close ranks, and so the white people did. But we were not in their ranks" (5). The narrative highlights from the outset that Antoinette's family does not belong to the white population of the island and so is not entitled to seek the whites' protection. Indeed, as Creoles and former slaveholders, they are bound to be neglected by both white Europeans and the black population of Dominica. Their vulnerability is exposed in the first violent attack by former slaves on Antoinette's family: their horse is poisoned and Antoinette's mother, Annette, claims that the family is "marooned" (6). Besides abandonment, 'maroon' also denotes a "fugitive slave." This reference to slavery may suggest that Annette's past, and more concretely her being the wife of a slaveholder, determines both the present of the family and their future. Furthermore, the racial implication of the term may suggest that the family's Creoleness condemns them to catastrophe and abandonment.

The brutal killing of the horse has an impact on Antoinette's worldview: she recalls seeing the horse "lying down under the frangipani tree" (5). The allusion to nature anticipates what comes shortly after this finding: a sudden change in her perception of the Caribbean landscape. After narrating the finding of the horse's corpse, Antoinette vividly recalls her family's garden, describing how it looked before and after this first key event:

Our garden was large and beautiful as that garden in the Bible - the tree of life grew there. But it had gone wild. The paths were overgrown and a smell of dead flowers mixed with the fresh living smell.... Orchids flourished out of reach or for some reason not to be touched. One was snaky looking, another like an octopus with long thin brown tentacles bare of leaves hanging from a twisted root... The scent was very sweet and strong. I never went near it. (6)

The main idea in this quotation is that the family's garden has undergone an abrupt change. Before the turning point in the history of Antoinette's family, their garden was full of life, as implied in the allusion to the tree of life. However, the poisoning of the horse brings about wilderness and death: this 
hitherto paradisiac world grows wild and some of the flowers die. Among the flowers which grow out of the wild soil, there are orchids that must not be touched. This means that any attempt by Antoinette to interact with the landscape will not be fruitful at all, since at this moment the garden is dangerous.

The narrator's retrieval of this memory of the previously familiar garden become unfamiliar anticipates Antoinette's overarching feeling of displacement. The hitherto safe homeland can no longer be perceived as a home: now, it feels like a physical and psychological prison where Antoinette's family is trapped. As Inna Malissa et al. note, "a displaced person will feel disconcerted and the feeling of attachment to a certain place they were once familiar with will be unfamiliar to them" (115). So, in this first part of the narrative Antoinette will be suspicious of the Caribbean landscape and will remain at a distance from it. Actually, the garden has turned dangerous at the same time as her Creole family has become economically and emotionally defenceless, so she can be said to be aware that her family's Creoleness might be one of the reasons their native land has become threatening to them. Eventually, Antoinette's awareness of how dangerous her homeland has become will lead to a deep sense of deracination that negatively affects her Creole consciousness.

The construction of Antoinette's Creole identity is hindered by the grudge Dominican blacks bear against white Creoles. The internal narrator explains: "I never looked at any strange negro. They hated us. They called us white cockroaches" (9). She gives voice to a key memory in which a little black girl follows her singing "Go away white cockroach, go away, go away" (9). As Melanie Weaver argues, Antoinette has inherited from her mother "a legacy as an exile without a strong identity" (14). This legacy is Creoleness, a hybrid condition that, far from celebrating, the protagonist unconsciously eludes. Rather than construct a positive identity, at this point in the novel Antoinette metaphorically chooses exile by avoiding her Creoleness. This evasion is enhanced by her reaction when the black girl insults her: she is unable to articulate a message and runs away to find shelter. Her refuge is seclusion and paralysis: "I sat close to the old wall at the end of the garden. It was covered with green moss soft as velvet and I never wanted to move again. Everything would be worse if I moved" (9). On this occasion, Antoinette is on the verge of entering the garden that has been described as wild and dangerous. However, she does not interact with the landscape; she sits beside the wall at the end of the garden and remains paralysed. This element of paralysis and avoidance of her native land's nature is related to her aversion to accepting her Creoleness, which she sees as disempowering. 
The connection between the dangerous Caribbean landscape and Antoinette's emotional detachment from her Creole identity is further reflected in the following nightmare: "I dreamed that I was walking in the forest. Not alone. Someone who hated me was with me, out of sight. I could hear heavy footsteps coming closer and though I struggled and screamed I could not move" (11). The first element forefronted in this reconstruction is the forest. Like the garden, this forest is not a shelter for such a defenceless character as the Creole, but a potentially harmful setting. As Mojgan Eyvazi et al. explain, "this dream shows Antoinette's repressed fear and paranoia in her unconscious mind while it forecasts her fearful future that awaits her" (159). Taking into account Antoinette's fears as to her Creole identity, what is haunting her may be the reluctant attitude of Dominican blacks, as suggested by the presence of the unnamed person who hates her. In this case, her pursuer may be an embodiment of the little black girl who has insulted her or even an image that stands for the resentful Dominican black community. Not coincidentally, such an instance of repudiation has been internalised by Antoinette and has provoked a sense of fear and uneasiness in her. Once again, the landscape of the island proves detrimental to her welfare. Finding herself alienated in a hitherto familiar island, she is unable to find a way to change her situation for the better. As well as being troubled by a sense of impotence, her psyche is too troubled with questions to do with identity. Hence, instead of progressing, Antoinette has no alternative but to relive her past and compulsively repeat physical reactions such as struggling and screaming.

The emphasis put on Antoinette's troubled mind suggests that the Creole has contradictory views of the landscape of Dominica. Thomas Loe notes of such contradictions, "[1]eft to her own devices and without familial defences, Antoinette's later references to landscape clearly alternate between the security she feels and her continued sense of threat" (54). This alternation is reflected in the internal narrator's reconstruction of her thoughts after awaking from the nightmare: "I am safe... There is the tree of life in the garden and the wall green with moss. The barrier of the cliffs and the high mountains. And the barrier of the sea" (12). To comfort herself, she opposes a view of the Caribbean landscape to the threatening natural world depicted in the dream: Antoinette argues that she feels safe as she realises that the natural elements of Dominica are supposed to protect her. In this case, the barrier which the island's geography provides does not entail imprisonment; rather, Antoinette perceives the Caribbean landscape as an element that protects her against further attacks. However, this positive depiction of Dominica's natural 
world proves illusory. Immediately afterward, she describes the grass as "razor grass" and highlights that she saw a snake (13). So, the apparently soothing effect that the nature of the island had on Antoinette after her nightmare has vanished in no time. Actually, she is in two minds about her degree of connection with the landscape of Dominica: while she tries to rely on the protection that her native country ought to provide her, she is aware that Dominica has become a place that is threatening her welfare.

As a consequence of this inconsistency, Antoinette is also doubtful about her Creole consciousness: whereas she understands that her family is hated, she clings to her homeland at both an unconscious level and a conscious one. With regard to the former level, she suggests her attraction to Dominica's soothing landscape in the aforementioned post-nightmare reflection. With regard to the latter one, she makes it clear that she does not want to leave the island. This unwillingness can be seen when her mother informs her second husband (Mr. Mason) of her desire to leave Coulibri. As Antoinette-as-narrator highlights, "I knew that we were hated — but to go away.... for once I agreed with my stepfather. That was not possible" (15). At this stage in the narrative, the internal narrator recollects her agreement with Mr. Mason because leaving her birthplace would have implied deracination. This stance conveys that, her fear and her doubts notwithstanding, the Creole protagonist is somewhat attracted to Dominica. This tension reflects the complexity of Antoinette's hybridity and anticipates that, throughout the novel, her Creole consciousness will be modified as her (dis)connection with her native landespecially with Dominica's landscape-evolves.

\section{DOMINICA'S LANDSCAPE AS A SELF-EMPOWERING PLACE}

The turning point in the construction of Antoinette's Creoleness is her marriage to an English man. ${ }^{1}$ Given Dominica's status as a colony of the British Empire, this representative of the male English coloniser is apparently destined to provide the Creole with the metaphorical — and even physical — shelter that she has been seeking. Nevertheless, he proves an unsympathetic husband who, far from protecting his defenceless wife, is set on making her more insignificant and ultimately shattering her endeavour to construct a positive cultural

\footnotetext{
${ }^{1}$ Although the name of Antoinette's husband is never mentioned in Wide Sargasso Sea, scholars commonly refer to this character as Rochester on the grounds that this novel is a rewriting of Jane Eyre. He will be referred to as Rochester throughout this article.
} 
identity. As he admits, "I did not love her. I was thirsty for her, but that is not love" (58). Rochester's lack of affection is accounted for by the fact that his marriage to Antoinette has been arranged. His father has disinherited him and thus he feels the need to travel to the unfamiliar island of Dominica with the aim of regaining his authority. As Delia Caparoso-Konzett explains, "his colonial unconsciousness, narcissistically wounded by that which negates its control, turns upon itself in a desperate effort to possess that which it never really had" (138). Rochester's attempt to exert his power and influence to the detriment of his Creole wife is first performed in his becoming the internal narrator of the novel. However, this confiscation of the narrative voice paradoxically grows destructive of his conceitedness since it exposes his weaknesses, and this vulnerability is increased by the account of his edgy relationship with Dominica's landscape.

Rochester emphasises the island's landscape from the beginning of his narrative: "Everything is too much, I felt as I rode wearily after her [Antoinette]. Too much blue, too much purple, too much green. The flowers too red, the mountains too high, the hills too near. And the woman is a stranger" (42). The parallelisms in this description enhance the oppressive force that Dominica's natural world exerts on this man. Rather than a coloniser who was supposed not to be weakened by this Caribbean colony, he is made uneasy and weary by the uncanny island. Besides highlighting the negative effect of the island's landscape, Rochester foregrounds that his wife is a stranger, therefore linking the Creole to Dominica's natural world. In this sense, Rochester points to a change in the relationship between Antoinette and place: whereas there was utter disconnection between the frightened early adolescent and the hostile nature of the island, now the (male) internal narrator bridges the gap between the Creole and the hitherto thorny landscape. In Jessica Gildersleeve's words, "the tropical island and Antoinette herself become 'entwined in Rochester's mind,' so that both come to be seen as exotic and dangerous, but also capable of undermining his corporeal control and his superiority" (36). As Gildersleeve suggests, the stronger link between Antoinette and Dominica's landscape is potentially detrimental to Rochester's apparent place in the hierarchy. Indeed, both of them entail a degree of danger that thwarts the husband's plan to possess his two objects of desire: his wife and the island.

Antoinette's growing attachment to her native land is further enhanced by the second internal narrator's emphasis on the clash between his and Antoinette's respective native lands. After an opulent dinner, Antoinette wants to 
confirm whether what she has heard about England is valid. Rochester-as-narrator reproduces her question: "Is it true,' she said, 'that England is like a dream? Because one of my friends who married an Englishman wrote and told me so. She said this place London is like a cold dark dream sometimes. I want to wake up."' (49). In this recollection, the narrator juxtaposes Antoinette's voice and that of her acquaintance by means of an embedded instance of direct speech that literally reproduces the voice of the Creole's acquaintance. This juxtaposition implies that Antoinette herself shares her friend's impression of London as a "cold dark dream" from which she wants to awaken. The moment parallels Antoinette's depiction of the Caribbean landscape in the first stage of her identity-construction as a result of both her fears and her sense of alienation. Here, as the voices of Antoinette and her acquaintance merge, the Creole covertly expresses her aversion to England, and this is the reason she decides not to use the indirect style in the report of her friend's stance.

Rochester-as-character seems to notice Antoinette's hint, since he replies, "This is precisely how your beautiful island seems to me, quite unreal and like a dream" (49). This answer might be read as a reproach to Antoinette, since his view of Dominica is analogous to his wife's opinion of England. The process of alienation Rochester undergoes is diametrically opposed to his wife's in this second stage of her identity-construction: judging by how she refers to England, it seems that her aversion to Rochester's native land is making her feel less uneasy in Dominica. She might be realising unconsciously that journeying to an unfamiliar country would accentuate her alienation as a Creole woman living in England and married to a coloniser. Hence, aware of her Creoleness, she might be unconsciously clinging to Dominica. As a result of this attachment, her interaction with the Caribbean landscape is no longer affected by fear: she tells Rochester that "the land crabs are harmless" and that "our snakes are not poisonous" (54). As Carine Mardorossian maintains, "it is no coincidence that a more unidimensional Rochester cannot relate to the tropical landscape that surrounds him, while the more complex protagonist Antoinette can and does in a profound way" (113). While Rochester's onesidedness prevents him from adapting to the colony, Antoinette's manifold identity translates into a remarkable capacity to overcome her fears and slowly embrace her Creoleness. In this sense, the previously hostile-seeming Caribbean landscape becomes an ally to the complex Creole, enabling her to construct a positive identity in contrast to the narrow psyche of the monolithic British coloniser. 
The increasingly strong alliance between the Creole and the Caribbean landscape culminates in Antoinette's assertion of her sheer identification with her native place. This identification occurs when she momentarily resumes the internal narration in order to recall her visit to the house where Christophine - her former black nurse-dwells. Antoinette sits under a mango tree and makes a powerful assertion that proves her positive evolution in the construction of her cultural identity: "The sky was dark blue through the dark green mango leaves, and I thought, "This is my place and this is where I belong and this is where I wish to stay" (68). The reconstruction of Antoinette's impressions at Christophine's proves fundamental for the understanding of how this character's Creole consciousness has evolved since she married the Englishman. Unmediated by the commanding male narrator, Antoinette's viewpoint at Christophine's reveals her true feelings towards both nature and her Creole identity. As can be seen in Antoinette's report, the positive portrayal of place shows that she is more attached to Dominica's landscape than she was before marrying Rochester.

As Mary Lou Emery notes, at this point in the narrative "Antoinette makes it clear that her quest involves "place' rather than "who"' (45). This assertion strengthens the idea that Antoinette is aware of her hybrid identity and that she embraces it. In this context, she might give less prominence to the search for a person to lean on because it is precisely a series of people-especially black Dominicans and Rochester-that have made her feel alienated. What Antoinette desires is to live in a physical setting where her identity is not shattered, but unified. As Antoinette implies (judging from her stream of consciousness), this setting is bound to be Dominica because she feels identified with it. By foregrounding her attachment to Dominica's landscape, the Creole grows empowered as she actually downplays the protection the colonising British husband was expected to provide her. Moreover, such a link reveals the positive complexity of Antoinette's Creole consciousness, she having supposedly overcome her worries about the legacy of her exploitative family in order to embrace her identity as a Caribbean Creole.

By the time Rochester resumes his internal narration, he has become aware that his stay in Dominica is disempowering him: "There would be the sky and the mountains, the flowers and the girl and the feeling that all this was a nightmare, the faint consoling hope that I might wake up" (76). Aware of the stronger link between the Creole and her native land, he forms a plan for deracinating her. First, he has sexual intercourse with a servant called Amélie. Nonetheless, what most strikes Antoinette is Rochester's decision to 
call her Bertha. This clear intertext refers to the name of Rochester's Creole wife in Jane Eyre and anticipates the confinement of Antoinette. By calling her Bertha, Rochester deals a fatal blow to the Creole's place in the marital hierarchy, and he recalls her response as follows: "Tears streamed from her eyes" (94). Such a response implies that the female protagonist feels humiliated for having been dispossessed of her name. Unable to answer back, she seems to have internalised that she is eternally alienated within the marital sphere. As Emelie Söderberg argues, by renaming Antoinette "the husband pressures her into leaving her identity as a West Indian by succumbing to her other sense of self" (23). Thus, Antoinette finds herself forced to choose her English side, with which she has been previously shown to be at odds. Hence, the strength she has shown in asserting that she belongs in Dominica gives way to a deep feeling of despondency and resignation. In Söderberg's words, the husband "enhances her anxiety by forcing her to choose sides and by emphasizing the fact that she does not really belong on either side" (23). Therefore, even if the couple were to continue living in the island, Dominica would apparently never become a completely homelike setting for the Creole.

Suddenly, Antoinette falls into madness and develops a growing tendency to drink and a fierceness that Rochester reports as follows: "I managed to hold her wrist with one hand and the rum with the other, but when I felt her teeth in my arm I dropped the bottle" (95). Antoinette's attack marks a turning point in the narrative. It precipitates Rochester's preparations to leave Dominica and ultimately uproot his wife: "She said she loved this place. This is the last she'll see of it.... She's mad but mine, mine" (107). Rochester's tone is categorical and enhances his joy in carrying out his self-empowering plan. His unequivocal mood can be clearly seen in his statement that his wife will no longer see the place to which she feels attached. Removing the Creole from a setting which has dwarfed Rochester, he will have no obstacles to benumbing his wife. Indeed, his endeavour culminates in his incarcerating his presumably mad wife in the attic of his mansion at Thornfield. Nevertheless, the supposedly helpless position of the Creole in the English house is reversed in terms of narrative prominence, since Antoinette once again interrupts the narrative of her dominant husband. Such an interruption demonstrates that Rhys's concern is to fully explore the figure of Rochester's hitherto silenced Creole wife. As Tammy Lai-Ming Ho contends, "Rhys' attempt to narrate the story of Antoinette in Wide Sargasso Sea blocks the narration of ... Mr. Rochester, who is reduced to a marginal character and only appears, cameo-like, in the last part of the book" (29). 


\section{THE AFFIRMATION OF CREOLENESS AT THORNFIELD}

Antoinette's internal narration at Thornfield revolves around the effects of her imprisonment on her identity-construction. Unable to find a mirror or an accessible window, she has developed a deep sense of alienation: "What am I doing in this place and who am I?" (117). As can be inferred from her ruminations, Antoinette is unable to realise the purpose of her stay in the attic, and her confusion contributes to her puzzlement about her identity. Since she cannot perceive a physical reflection of the outside or even of her countenance, she resorts to a tool that has proved powerful for her aim of making her (hi)story visible: her memories.

As Teresa O'Connor observes, the Creole "relies on the memories of her home to help her struggle against those forces that threaten to destroy her, to limit her natural sensuality, and to deprive her of autonomy and freedom" (147). Hence, Antoinette resorts to free association and dreamlike figments of memory in order to reconstruct a positive Creoleness that the world of the British Empire reduces to pettiness. First, she associates her mother with the pattern of a tapestry: "Looking at the tapestry one day I recognized my mother dressed in an evening gown but with bare feet" (117). In this context, she may identify the figure of her mother in the tapestry because she is in search of an identity, and it is by reconstructing her past in Dominica that she may weave the identity she seeks. Thus, the role of place in this novel is again brought to the fore as Antoinette's connection to it helps her develop a strong Creole consciousness. That identification in the tapestry is followed by another association that reveals that Antoinette has embraced her Creole identity and, most importantly, that she favours her native land to the detriment of the Britain from where her whiteness comes.

Antoinette gives free rein to her imagination juxtaposing her red dress with the scent of Dominican nature: "The scent that came from the dress was very faint at first, then it grew stronger. The smell of vetivert and frangipani, of cinnamon and dust and lime trees when they are flowering" (120). The Creole's sensory experience brings her closer to her now faraway native land, and this connection with Dominica's natural world is, as has been explored throughout this article, of great relevance for understanding the evolution of Antoinette's identity. The threatening trees and the strong-smelling orchids have given way to an enchanting nature that emits a pleasing scent, and this change reflects that the Creole now feels attached to Dominica and at ease with her hybridity. The retrieval of Caribbean landscape from the 
attic is by no means inconsequential. As Heta Pyrhönen claims, Antoinette "is referring to her resolve to become mistress of herself, decide upon her fate, and go "home" (103). Taking such an endeavour into account, it becomes evident that, though having previously been puzzled as to her identity, she now resorts to memories related to place in order to assert her positive Creole identity. Hence, the retrieval of such memories demonstrates that she is unconsciously leaving behind her English origins and clings to her Caribbean culture, in which she is likely to find the protection and companionship she lacks in her oppressing room.

\section{CONCLUSION}

The wavering relationship between the female protagonist of Wide Sargasso Sea and Dominica's landscape is key for the understanding of how complex Antoinette's Creoleness is. Indeed, Rhys's reconstructing Antoinette's process of identity formation and ultimately strengthening her emotional ties with Dominica provide a manifesto that destabilises Eurocentric views that neglect the multifariousness and charm of West Indian culture. In Sandra Drake's words, this novel is "a victory over death itself by changing the cultural and belief system from a European to an Afro-Caribbean one" (205). What Drake suggests is that Rhys set her heart on changing the perspective from the Eurocentric one to that of a member of the colonies. Enacting such a desire, Antoinette takes the role of an internal narrator who recollects her past in Dominica and, most importantly, her psychological maturation through her relationship to Caribbean nature. In doing so, Antoinette uses the mastery of her own destiny to give voice to a story which had been silenced by the dominant imperial discourse and which reveals her complex but fascinating identity.

\section{WORKS CITED}

Antinucci, Raffaella. "Jean Rhys and the Duplicity of Landscape." Scritture femminili: da Mary Wollstonecraft a Virginia Woolf, edited by Andrea Mariani, Francesco Marroni, and Massimo Verzella, Aracne, 2009, pp. 273-83.

Balaev, Michelle. "Trends in Literary Trauma Theory." Mosaic, vol. 41, no. 2, 2008, pp. 149-65.

Caparoso-Konzett, Delia. Ethnic Modernisms: Anzia Yezierska, Zora Neale Hurston, Jean Rhys, and the Aesthetics of Dislocation. Palgrave Macmillan, 2002. 
Drake, Sandra. "Race and Caribbean Culture as Thematics of Liberation in Jean Rhys's Wide Sargasso Sea." Wide Sargasso Sea, by Jean Rhys, edited by Judith L. Raiskin, a Norton critical edition, Norton, 1999, pp. 193-206.

Emery, Mary Lou. Jean Rhys at "World's End": Novels of Colonial and Sexual Exile. U of Texas P, 1990.

Erll, Astrid. "Locating Family in Cultural Memory Studies." Journal of Comparative Family Studies, vol. 42, no. 3, 2011, pp. 303-18.

Eyvazi, Mojgan, Shirin Pourebrahim, and Nasim Sahebazmani. "Evaluation of Intertextuality and Irony in Jean Rhys's Wide Sargasso Sea: A Postmodern Outlook." International Journal on Studies in English Language and Literature (IJSELL), vol. 2, no. 9, 2014, pp. 153-64.

Gildersleeve, Jessica. "Jean Rhys's Tropographies: Unmappable Identity and the Tropical Landscape in Wide Sargasso Sea and Selected Short Fiction." Etropia, vol. 10, 2011, pp. 32-38.

Gregg, Veronica M. Jean Rhys's Historical Imagination: Reading and Writing the Creole. U of North Carolina P, 1995.

Lai-Ming Ho, Tammy. Neo-Victorian Cannibalism: A Theory of Contemporary Adaptations. Palgrave Macmillan, 2019.

Loe, Thomas. "Landscape and Character in Jane Eyre and Wide Sargasso Sea." A Breath of Fresh Eyre: Intertextual and Intermedial Reworkings of Jane Eyre, edited by Margarete Rubik and Elke Mettinger-Schartmann, Editions Rodopi, 2007, pp. 49-61.

Malissa, Inna bte Che Jamal, Hardev Kaur, and Manimangai Mani. "A Study of Displacement in Jean Rhys' Novel Wide Sargasso Sea." Advances in Language and Literary Studies, vol. 5, no. 5, 2014, pp. 111-18.

Mardorossian, Carine M. "Caribbean Formations in the Rhysian Corpus." Jean Rhys: Twenty-First-Century Approaches, edited by Erica L. Johnson and Patricia Moran, Edinburgh UP, 2015, pp. 107-22.

Nora, Pierre. "General Introduction: Between Memory and History." Realms of Memory: Rethinking the French Past, 3 vols., Columbia UP, 1996, pp. 1-20.

O’Connor, Teresa F. Jean Rhys: The West Indian Novels. New York UP, 1986.

Pyrhönen, Heta. Bluebeard Gothic: Jane Eyre and Its Progeny. U of Toronto P, 2010.

Rhys, Jean. Wide Sargasso Sea. 1966. Penguin Books, 2000.

Savory, Elaine. The Cambridge Introduction to Jean Rhys. Cambridge UP, 2009.

Söderberg, Emelie. “'I Often Wonder Who I Am': Identity, Landscape and Sexuality in Wide Sargasso Sea." 15 Jan. 2010. Linnaeus U, student paper.

Weaver, Melanie B. Meeting the Madwomen: Mental Illness in Women in Rhys's Wide Sargasso Sea, Hijuelos's Our House in the Last World, and Garcia's Dreaming in Cuban. 2012. East Carolina U, Master's thesis. 


\section{KRAJOBRAZ KARAIBÓW I KONSTRUKCJA KREOLSKIEJ ŚWIADOMOŚCI W SZEROKIM MORZU SARGASOWYM}

\section{Streszczenie}

Artykuł analizuje powiązanie pomiędzy opisami miejsca a konstrukcją kreolskiej tożsamości w powieści Szerokie Morze Sargasowe autorstwa Jean Rhys (1966). Stawiam tezę, iż kreolska świadomość bohaterki powieści przechodzi ewolucję, której wyrazem jest jej relacja z naturą Dominki. Narratorka oddaje relację pomiędzy miejscem a tożsamością przywołując zdarzenia ze swojej przeszłości; szczególne znaczenie mają tu opisy jej interakcji z krajobrazem Karaibów na różnych etapach jej życia. Analizując powiązanie pomiędzy formacją tożsamości a krajobrazem Karaibów, artykuł ma na celu poszerzenie stanu badań nad procesem odzyskiwania pamięci w prozie Jean Rhys, jednocześnie rzucając nowe światło na kluczową rolę krajobrazu Karaibów w Szerokim Morzu Sargasowym.

Słowa kluczowe: Jean Rhys; krajobraz Karaibów; kreolska tożsamość; pamięć; Szerokie Morze Sargasowe. 